\title{
The Importance of Tasawuf Practice in the Life of Modern Society
}

\author{
Nozira Salleh \\ Faudzinaim Badaruddin \\ Rosmawati Rasit \\ Mohd. Haidhar Kamarzaman \\ Indriaty Ismail \\ Ahmad Yunus Mohd. Nor \\ Research Centre for Theology and Philosophy \\ Faculty of Islamic Studies \\ The National University of Malaysia \\ 43600, Bangi, Selangor, Malaysia
}

\begin{abstract}
Modern society today suffers from various social problems such as child abuse, child rape, domestic violence, gangsterism, vandalism and many more. The emergence of these various social ills stems from the empty and dead soul of society. Thus, this study examines Islamic mysticism which is believed to be the best mechanism for society to treat such problems and diseases because mysticism provides certain methods based on the Qur'an and Sunnah. This qualitative study uses library research such as books, journal articles, newspapers and magazines to find information related to the topic. The results of the study found that Sufism is indeed a holistic mechanism in restoring today's society from various negative diseases and social problems.
\end{abstract}

Keywords: Sufism, Soul, Spirituality, Social symptoms, Malaysia

\section{Introduction}

The life of modern society today has undergone a complex development involving the development of science and technology. Malay Muslim community in particular suffer from social change involves the transformation of a whole cultural life and to jeopardize the values of life and the value of religion in society. As a result, today's society is not only advanced in terms of science and technology, but they also face various social problems and diseases such as abortion, child abuse, child rape, domestic violence, prostitution, robbery, corruption, gangsterism, vandalism and others.

This social symptom occurs because it stems from the empty human spirit and soul. It can be likened to an empty container filled with air alone. The human soul and spirit must be filled with spiritual element that is to know Allah as the Creator of the universe, to practice what the Prophet SAW brought and to know the nature of man himself. This is because all aspects of a person's life depend on the spiritual element as the purpose of human creation is to worship Allah SWT. Indeed, science and technology cannot fill the void of the soul if it is not filled and filled with deeds of worship to Allah Almighty. Thus, the return of man to religion is the only best and holistic effort to cure these various social ills. In this case, Sufism is believed to be the best mechanism by going through certain methods to cure the soul of a human being who is hollow, sick and dead, which is seen as the basis for the emergence of various social problems. In other words, learning and appreciation of mysticism in the life of society, especially Muslims today is very important because the current of modernization has brought people increasingly neglected and careless with the teachings of religion.

\section{Definition of Tasawuf}

DBP Dictionary (1994) defines Sufism as a teaching (effort, path) to know and draw closer to God in truth. Next, it states that this knowledge is suluk knowledge and tarekat knowledge. The origin of the word Sufism has been disputed with various opinions and views. Sufism is said to be derived from the word $s \bar{u} f$ meaning fur which is a kind of coarse clothing made from animal fur. It was a garment for most Sufis in ancient times because it was the kind of clothing most preferred by the anbiya $\bar{a}$ ' and the șiddiqin as well as a syi'ar to the ascetics (Ibn Khaldūn t.th.).

In addition, there are also those who think that the term Sufism is attributed to a man named al-Ghaus bin Mar bin Ad bin Thabikhah bin Elyas bin Mazar who always isolated himself from society because he prayed to Allah in the Masjidil Haram (Mecca). However, he is better known as Sūfah bin Murah (Al-Jawzī 1987). Therefore, the Sufis are said to be dependent on him because of their position which is almost the same as him from the point of view of isolating themselves to devote themselves and worship Allah earnestly. 
Later, the term Sufism is also said to be derived from the word al-șaff which means the line either the struggle line on the battlefield or the front line when establishing prayers. This is because most Sufis are always in the front row during prayers in the mosque and during the war (A.H. Mahmūd 1974). Next, the word is also taken from the word $s a f w \bar{a}$, but the word is quite difficult to pronounce by the tongue of the Arabs, so it has been changed to süf $i$ which means purifying the heart and conscience towards Allah (Al-Syak'ah 1996). It is the most important content in the practice of Sufism, where it is better known as safā al-qalb lillāh which is clarity and silence of God (Nicholson 1951). In addition to all these opinions, the word Sufism is also said to come from ahl al-Suffah, namely the Companions of the Prophet who consisted of the Muhajirin and Ansar who had no heirs and relatives, the poor and homeless. Therefore, they only live in the foyer of the Prophet SAW Mosque in Medina. However, they are people who always worship and pray to Allah SWT. Their story was narrated by Imam al-Bukhari, from Abu Hurairah he said, "I have seen seventy people from among the Suffah members who live in that place." The number of those who lived in the Prophet's Mosque was 400 people (Al-Suhrawardī 1966).

Thus, the definition of Sufism according to the language perspective is seen from the point of view of the source of the term, where all the differences of opinion about it have shown a similar meaning that is spiritual. Therefore, the science of Sufism can be described accurately as the knowledge that brings a Muslim to Allah in the best possible way.

Furthermore, the meaning of Sufism in terms of terminology is seen according to the views of Islamic scholars who have various different definitions because they evaluate it from the point of view, observation and experience of each according to the time, atmosphere and development. According to al-Kattānī, Sufism is the path taken by anyone who supplies praiseworthy morals to a person (Al-Sullamī 1969). Some other Sufi figures state it as morality when with creatures and also when with God (Suhrawardī 1966). Al-Taftāzanī (1976) states that Sufism is basically morality because it can be considered as the spirit of Islam. In addition, al-Sya'ranī (1954) also defines Sufism as knowledge that arises from the hearts of the saints when they practice the Qur'an and Sunnah.

Next, Muhammad 'Alī al-Qashab defined Sufism as a noble morality, emerging in noble times, from a noble man with a glorified race (Al-Qusyairī 1972). Later, al-Baghdādī, on the other hand, defined Sufism as a noble morality, which emerged in the noble age from the hands of a noble person with a noble people. Abū Muhammad al-Jarīrī states that Sufism is a path of migration from bad morals to noble morals (Al-Tusī 1960). Whereas al-Ghazāli (1979) defines Sufism as a way to purify the soul from reprehensible morals and bad traits so that the human being can cleanse his heart from things that associate Allah and adorn his heart by always remembering Allah. For Ibn Khaldūn (1975), Sufism is to preserve the glory of manners with Allah in a deed, whether inner or outward practice by placing His hudud ahead of self-interest, always approaching God and praying to Him. Ma'rūf al-Kurkhī defines Sufism as a method of dependence on life from a servant to Allah SWT without being bound to creatures (AlSullamī 1969). Later, al-Baghdadī defined Sufism as a human relationship with Allah without any intermediary (Al-Tusi 1960). Through these opinions, it can be understood that Sufism is a method or way to guide people to bring themselves closer to God through the process of purification of the soul to have noble morals and perform good deeds of worship.

\section{Modern society and its problems}

Nowadays, modern society around the world in general and in Malaysia in particular is facing various problems or social ills that are worrying. Problems such as dumping babies everywhere, child abuse, child rape, domestic violence, children running away from home, prostitution, robbery, corruption, gangsterism, vandalism, drug abuse, reverse sex and others are getting worse and show an increase from time to time. All these problems have reflected that Malaysian society is now generally suffering from a relatively serious illness, and it requires more aggressive efforts to reduce the rate of such social problems.

This phenomenon of child abuse is no less great in the daily life of Malaysian society. It is a serious violation of a child's right to grow up in a healthy state. This abuse involves physical, emotional, sexual and neglectful abuse. The chests of local newspapers often report stories and load pictures of abused children. This means that the case is getting more serious with the increase in the number of cases from year to year, for example in 2017 it has recorded a total of 5537 cases. In addition, the seriousness of this problem is also reflected in the existence of a special line dubbed as 'teledera' by the Department of Social Welfare, Malaysia to make it easier for children or the general public to make direct reports of an incident of abuse (Norsaleha et.al 2018). Similarly, the case of teenagers who run away from home is one of the relatively serious and serious problems in today's society. This social problem recorded a total of 4,125 cases from 2017 to 2019 (Mymetro 2020). These negative actions are due to various factors such as the teenager disagreeing with his parents or guardians, having a family background that is often quarrelsome and unhappy, parents resisting relationships with boyfriends, sexual harassment or abuse by family members and wrong choice of friends in association. What is sadder is that most of these runaway girls have ended their refugee destinations in the brothel. Meanwhile, teenage boys are reported to be involved in many serious criminal cases such as murder, robbery, robbery and rape (Zakaria Stapa 2001). 
Then, another social problem that is rampant today is domestic violence. It is also referred to as domestic abuse and domestic violence. It is commonly described as violence or abuse of power in an intimate relationship between an individual (usually a man) trying to control and dominate his partner (usually a woman). Domestic violence also involves violence against children, parents or the elderly. However, the most victims of violence are women. Many wives who are involved in this problem have suffered physical and emotional trauma because they have faced a hot-tempered husband, beating feet and so on. Among the causes of domestic violence are jealousy, communication problems, psychological, sexual, family interference, economic and career problems. This violence has resulted in physical injury, psychological and emotional disorders (Mariny et. Al 2016; Zakaria Stapa 2001).

In addition, in some big cities such as Kuala Lumpur, behaviors such as free sex that can have side effects such as abortion for example appear to be germinating well, in fact it is moving towards an independent lifestyle or something that is considered trendy (Zakaria Stapa 2001 ). There are many factors that can be associated with this free sex behavior such as parental indifference in dealing with this problem when it comes to their knowledge, free and uncontrolled association among adolescents that causes them to go anywhere and with anyone, adolescents' attitude towards sex consideration of rewards and sins, problems in the family, entertainment center facilities, the influence of friends and the mass media and others (Idris Awang 1996).

In general, social problems and negative phenomena that occur in society today whether it is from the involvement of teenagers in serious forms of crime such as murder, robbery, rape or adult involvement related to corruption, murder and so on is a sign that society modern today is experiencing a critical social ills. The focus on solving social problems in this society needs to be looked at properly because the problem will certainly damage the society as a whole and at the same time the country.

\section{a-Problems of modern society}

In examining the emergence and transmission of various social problems that are spreading and worsening, it is better to look at and identify the factors to this problem to facilitate each member of society to play a role in rehabilitating it. In fact, modern society today faces various social problems because their spiritual aspects which are represented by universal noble values and recognized by every sane human being become marginalized and sunk. This is because society has been dominated by foreign ideologies such as secularism, liberalism and others, all of which have led them away from the appreciation of religion in their lives. This understanding dominates every niche of human life. Secularism has succeeded in inviting various chronic problems to society due to the separation of daily life from religion so that in the view of some communities, religious affairs are personal rights that cannot be touched anymore, while daily affairs are believed to have nothing to do with religious affairs (Wan Mohd. Nor 2001). Liberalism, which is seen as an ideology and philosophy, has supported the freedom of individuals in all aspects of life, including political, economic, social and religious. Such freedom has resulted in ideologies that reject religion and values that cause significant social change (Budhy Munawar 2010; JAIS 2014). The negative impact, these ideologies have adversely affected the spiritual and mental development of Muslims in particular. As a result, their souls are increasingly empty from day to day, and they are further away from religion. Thus, it has caused them to act outside the humanitarian box by engaging in various destructive social problems.

In addition, there are also other more specific factors such as complete dependence on the money. People in this modern age are very busy looking for their own pleasures and interests due to the dependence of their minds and souls on money. In money they put their trust in peace and good fortune so that in the eyes of some people, it can replace God. This is because money is believed to be used to change whatever man wants in his life. Simply put, it can be said that modern society is experiencing a situation of possession and mastery of the symbol of wealth, because it is driven by the view that those who have a lot of money and property are superior human beings in a society. This means that when a person puts money as a priority in his life, then the values of life and religion will be indirectly marginalized. Thus, it is not surprising that today's modern society has a pattern of social relations that are not well implemented because most of them have shown negative traits in themselves such as rude in conversation and association, greed, selfishness, lack of sense of responsibility, no rational, reckless, violent, religious values are loosening among them and so on (Ahmadi 1990). The passion in living a modern life that is more principled to these materialistic considerations causes human beings to become so greedy that the judgment of lust overpowers the mind in all decisions made. As a result, this materialism leads human beings to the goal of materialism and luxury in life so that the values and measures of good-bad, noble-humble, backward, and even sometimes the value of truth and justice are determined by the elements of materialism. The rich are rich in material elements that are always true and win in the chess of various sectors of life (Muhammad 1990; Zakaria 2015). Thus, when human beings have put money and property as everything in life, then the needs of the soul will be neglected by itself, and this is easier for him to suffer from various social problems and diseases such as corruption, robbery, adultery and so on.

The presence of various sophisticated technological tools is seen as one of the factors that cause today's society to face various social symptoms. 
Mass media is one form of technological advancement in the field of information and communication. The mass media is a major contributor to the moral collapse among today's youth (Sohana 2016). It is evidenced by the existence of television programs in particular that are more concerned with entertainment than information, by presenting various Western, Korean, Chinese and Hindustani film screenings which some of these shows reject the oriental elements that are ingrained in the soul of society. Similarly, with various websites such as facebook, twitter, instagram and youtube, it is easily accessible and easily available a variety of good and bad information. They easily browse pornographic websites, watch violent acts and then imitate and so on. All this directly and indirectly has exposed teenagers in particular to many bad things and even damaged their morals (Wan Norina et. Al 2013; Sohana 2016).

All these factors in fact have driven and caused members of society today to fall into various social problems. Sometimes a person's involvement in certain social problems, is not due to the shallowness of his knowledge, but because of the problems of the hearts of those who are sick and dead due to being influenced by beliefs that keep him away from religion and also sleepy and influenced by electronic media, mass media and sites -various websites. Thus, to solve this problem, Sufism is seen as the best mechanism to reviving the dead heart to return to Allah.

\section{Tasawuf and Its Solution Methods}

The social problems in society today are due to the lack of appreciation of members of society for spiritual values because they are far from the Qur'an and Sunnah. An empty soul or spirit is the main cause of the occurrence of these various social problems. The soul will be full if it is filled with spiritual food such as knowing oneself and its Creator, doing good deeds to Allah SWT, carrying out every command of Allah and avoiding all the prohibitions of Allah SWT. This is because the demands of nature of every human being require a constant interaction between a servant and his Creator as it has always been emphasized that Islam is not a static theory, but a two-way relationship between beings and the Creator. In Islam, there is no distinction between worldly and spiritual aspects because belief and obedience to Allah SWT occurs in all aspects of life. Thus, such religious life is in line with and in accordance with the demands of religion which commands its followers to practice religious life in total (Othman 2001).

Thus, the use of the framework of knowledge and practice of Sufism for the purpose of purifying the soul to draw closer to God and at the same time, purifying and avoiding all immoral acts and activities, is seen as a holistic and sustainable step. In this case, the importance of Sufism is evident through the writings of Muhammad al-Ghazali (1967) who called for a return to the value of Sufism because it trains and develops oneself towards perfection and is able to see the world as a small thing and see the hereafter as the end of life. Similarly, the opinion of Said Hawwa (1999) who described only Sufism as the best alternative in educating human beings by humbling and obeying God Almighty. Later, he also stressed that spiritual education (Sufism) is the basis of a person's success in life.

In modern life, mysticism which provides various formulas and certain methods such as instilling the importance of cultural knowledge, reflection, contemplation, remembrance, repentance and so on become a remedy to overcome the spiritual crisis of modern man who has strayed from the true path of Islam until he no longer knows who he is and the purpose of his life in this world. The application of mystical knowledge and practice in modern life not only benefits to restore spiritual values or closer to God, but also beneficial in various fields of modern life today. Sufism is able to clean the way of life of modern society that is always shrouded in negative things, purify the orientation of their lives that are sometimes lost in the direction of its purpose, straighten their mixed intentions for the sake of this world and the hereafter and set the way of treatment only. What is clear is that the practice of Sufism can educate and develop the potential elements of the human body and soul which is the main cause of the formation of human emotions by making it calmer and balanced (Yusoff 1989; Rahimin 2005; Othman 2001).

In addition, the importance of appreciating Sufism is also seen through the purpose of tawassuf itself. According to al-Qarani (1986), there are several goals of Sufism, to know and worship Allah with full earnestness, purification of the soul to achieve makrifatullah and form a prosperous society. Therefore, society needs to be exposed and applied to this knowledge and practice that contains perfect spiritual values. For example, in the problem of social symptoms among adolescents. A teenager who understands Sufism will stay away from harmful things because he believes his goal and purpose in life is because of Allah SWT alone.

Thus, in Sufism, there are certain methods and values that are important to be applied by modern society, especially Muslims to avoid and cure various social ills that plague society. Among them are:

\section{Purification of the soul (tazkiyat al-nafs)}

Among the main and more specific methods in the appreciation of Sufism is the process of purification of the soul (tazkiyat al-nafs) which is believed to be able to restore and develop spirituality as well as able to deal with social problems of society. 
It coincides with what Said Hawwa (1999) states that the process of repair is through this process of purification of the soul. From the point of view of definition, tazkiyah is a persistent and earnest effort to cleanse and purify a human being from bad and vile traits (Ansari 1983). It can also be likened to the purification of human lust which is the root of all reprehensible traits. Later, the purification should also be followed by efforts to fill and adorn oneself with noble attributes (Sulaiman 1992).

Tazkiyat al-nafs meant in the organization of Sufism is an effort to direct and nurture human al-nafs so that it becomes in line with the will of Allah SWT. It is an attempt to deny the will of al-nafs al-ammarah and replace it with al-nafs al-mutmainnah. Simply put, it is understandable that this purification process involves two important methods. The first method is known as takahalli which is a persistent effort to scrape and remove all bad qualities such as al-kufr, al-nifaq, al-shirk, al-riya ', al-bukhl, al-ghurur, al-ghadab, hub al-dunya, ittiba' al-hawa and many others. Then, the second method is known as tahalli which is an effort that replaces the discarded attributes with good attributes such as al-ikhlas, al-sidq, al-syukr, al-sabr, al-zuhd, mahabbah, al-khawf, al-raja' and many others. Thus, this method can be likened to 'throw away the murky, take the clear'. Although the process of cleansing and purifying the soul is a difficult process because it fights against something invisible, even it is in the human body, but it is not impossible to do. Its success depends on the faith and sincerity of a human being (Zakaria Stapa 1999; Sulaiman 1992; Othman 2001).

Usually, a person who appreciates Sufism by always practicing tazkiyat al-nafs or purifying the soul in his life will always protect himself from any vices or sins whether small or large. His soul became strong and not easily influenced by so many negative elements out there. When this situation occurs in every member of society, then it is not impossible for the Muslim community in Malaysia in particular to recover from all the social problems that infected him before.

\section{Ihsan}

Next, the process of purification of the soul can also be carried out at a level or kaifiyah called ihsan or a level of confidence and the presence of a sense and awareness that Allah always sees what a human being does (Zakaria Stapa 1999). Achievement at the level of ihsan is the most important thing that causes other attributes such as zuhud, ridha, qanaah, syukr, tawakkal and sabr will follow to adorn oneself and then form a Muslim personality that has praiseworthy morals.

The main element that is considered ihsan is in the prayers performed by a Muslim because it must be done with full perfection both outwardly and inwardly. If a Muslim performs prayers like a small child who only performs bowing, prostration and certain other acts without realizing the purpose of the prayer itself, then it is considered useless. The prayer performed should reach the level of ihsan which is concluded as 'you should worship Allah as you can see Him, if you do not see it, then know that Allah always sees you.' So the method said 'you can see God in your prayers', of course it is very far to taste it except whom He wills, then what remains is the second method which is 'we are still seen by God' (Othman 2001). Every Muslim must believe and be convinced that all his movements are indeed seen and observed by God at every moment and wherever he is, and nothing escapes His knowledge. Therefore, when a Muslim has achieved the dignity of compassion in his prayers, then of course in his daily life he will also feel noticed by Allah so that he is afraid to do bad deeds even in a state of loneliness. This means that the effort and achievement of kindness in prayer can also be used as a boundary for a person not to do bad deeds in daily life. This directly and indirectly has caused every member of society to stay away from negative things that can damage themselves, religion and even the country (Zakaria Stapa 2004).

\section{Zuhud}

Appreciation of Sufism is the solution to the materialistic ills of society today. The best way to improve oneself from such traits is to subdue lust by strengthening the spiritual within. It is found in the value of Sufism which is asceticism. Zuhud is a simple attitude in life, not to exaggerate and not to love the world so much that it forgets the afterlife. The world is a tool or path for human beings to get closer to Allah SWT and achieve life in the hereafter. In this regard, Imam al-Ghazali (1988) describes asceticism as "the act of one who rejects something desired to get something more valuable." He often stressed that every human being is very necessary to the life of the world and its contents, but it should be taken accordingly so that it does not become an obstacle to get closer to Allah SWT. Similarly, Sayyid Qutb (1982) who asserted that asceticism does not mean that Allah SWT commands Muslims to flee from the world in which they live, but they must go through life in this world with full awareness that their purpose is created in this world. to perform acts of worship to Allah SWT and use it as a way to the hereafter. In today's context, asceticism can be likened to a nature that is the opposite of materialistic nature. An ascetic Muslim is a person who has no materialistic nature or love of the world.

He is a modest person in matters of worldly life and relieves every sustenance bestowed by Allah SWT on him. He will not chase to get more wealth until he forgets the deeds of worship to Allah and will not use the wrong way to get sustenance, in fact he is confident that the grace and sustenance of Allah SWT will be given to its owner. 
Therefore, when every Muslim practices this attribute, then there will be no more problems of robbing, stealing, robbing and various other bad deeds. On the other hand, his life is more blessed by Allah SWT and the people around him will love him. His life is more orderly and calmer, his life is more balanced for the world and the hereafter, making him more patient, resilient and strong in the face of any difficulties and tests given by Allah SWT and he will keep away from doing things that are contrary to the Shari'ah. (Nozira 2014).

\section{Conclusion}

Today, it can be seen that the government, for example, does not stop promoting various plans to improve the increasingly critical state of society with various social problems that are increasingly complex. Program such as the 'penerapan nilai-nilai Islam, masyarakat penyayang, rumahku syurgaku, rakan muda, budayaikram and jaya waris are among the determination and commitment of the government in efforts to recover society from social ills and at the same time create a society of noble morals. In Islam, the science of Sufism is seen as the best method to obtain human perfection based on the value of Sufism that can be practiced by all groups. The value of Sufism is seen as the basis of the perfection of worship and can be used as a way to improve the human self. Humans can perform worship in practice as well as be able to maintain it consistently and well, get rid of vile traits, applying praiseworthy moraland maintain good relations among human beings through the appreciation of Sufism. Sufi approach; tazkiyat al-nafs, ihsan and zuhud as revealed in the whole framework of methodology which is a continuous and serious practical approach or practice that can guarantee effectiveness in the recovery of the human soul and at the same time form a sustainable personality as evidenced by the historical journey of Islamic civilization. An understanding of the value of Sufism must be educated to the community so that the community can practice in daily life. Therefore, it is important for the whole society today to make Sufism as one of the continuous ways of life to get rid of all the vile traits and at the same time form good qualities in oneself and society.

\section{References}

Ahmadi. 1990. Ilmu Sosial Dasar. Jakarta: Rineka Cipta

Ansari, F.R.1983. Tazkiyah: the role of the Prophet. Islamic Order. 5(4):11-

Budhy Munawar. 2010. Argumen Islam untuk sekularisme. Indonesia: Grasindo

Al-Ghazali. 1988. Ihya' 'Ulumuddin. Terj. TK.H. Ismail Yakub. Jil. 1-8. Kuala Lumpur: Victory Ajensi.

Al-Ghazālī, Abū Ḥāmid Muḥammad ibn Muhammad. 1979. Al-Munqiz min al-Dalāl. Abd. al-Halim Mahmud (pnyt.). Beirut: Dār al-Kitāb al-Lubnānī.

Al-Ghazālī, Muhammad.1967. Rakā'iz al-īmān baina al-Aql wa al-Qalb.Kuwait: Maktabah alAmal

Said Hawwa. 1999.Tarbiyatunā al-Ruhiyyah. Kaherah: Dar al-Salam.

Ibn Khaldūn. 1975. Syifā'u al-Sā'il li Ibn Khaldūn. Muhamad bin Tawait al-Thanji (pnyt.). n. p.: n. p.

Ibn Khaldūn. t.th. Al-Muqaddimah. Kaherah: Dār al-Sya'bi.

Ibn al-Jawzī. 1987. Talbīs 'Iblīs. Beirut: Dārul Kitāb al-'Arābī.

Idris Awang. 1996. Kelakuan Seks Bebas di Kalangan Remaja Melayu. Jurnal Usuluddin 5(Dec): 177-192.

Jabatan Agama Islam Selangor. 2014. Liberalisme \& Pluralisme Agama: Hakikat dan Impak. Selangor: Bahagian Penyelidikan \& Pembangunan JAIS.

Mariny Abdul Ghani, Sabasiah Husin \& Azizul Mohamad. 2016. Isu Keganasan Rumahtangga:

Keberkesanan Perkhidmatan Kaunseling Berdasarkan Perspektif Klien Wanita Mangsa Penderaan. Jurnal Kemanusiaan 14(2):1-9

Mohd. Sulaiman Yassin. 1992. Akhlak dan Tasawuf. Bangi:Yayasan Salman

Muhammad Syukri Salleh. 1990. Pembangunan untuk manusia atau manusia untuk

pembangunan: Analisis tentang manusia dalam pembangunan berteraskan Islam. Dalam Konsep dan perlaksanaan Pembangunan berteraskan Islam. Pulau Pinang: USM

Mymetro. 2020. Ingin Kebebasan Punca Kanak-kanak Lari dari Rumah. hmetro.com.my/mutakhir. Retrieved: 29 Ogos 2020.

Norsaleha, Nabilah, Zetty Nurzuliana, Norhafizah, Kamal Azmi \& Norbahiah. 2018. Statistik Kes Penderaan Kanak-kanak di Malaysia: Satu Analisis. International Journal for Studies on Children,Women, Elderly and Disabled 5(Oct.):17-24.

Nozira Salleh. 2014. Kepentingan Penghayatan Zuhud dalam Kehidupan. Dalam Haziyah Hussin, Nozira Salleh \& Ahmad Munawar Ismail (Ed.). Warisan Kecendikiaan Islam(Pemikiran dan Pembangunan Islam). pp. 615. Bangi: Fakulti Pengajian Islam, UKM

Nicholson, Reynold A. 1951. Al-Sufiyyah fi al-Isläm. Translated by Nurudin Syaribah. Kaherah: n. p.

Othman Napiah. 2001. Pengantar Ilmu Tasawuf. Johor: Penerbit UTM

Al-Qarani. 1986. Prinsip-prinsip tasawuf Islam. Translated by Muhammad Zaidi et. Al. Negeri Sembilan:Jabatan Mufti Kerajaan Negeri Sembilan. 
Al-Qusyayrī, Abu al-Qāsim Abdul Karīm bin Hawāzin. 1972. Al-Risālah al-Qusyayriyyah.

Edited by Abd al-Halim Mahmud dan Mahmud bin al-Sharif. Vol. 1 \& 2. Kaherah: Dār al-Kutub al-Hadithah.

Rahimin Affandi Abd. Rahim. 2005. Citra Islam dalam pembentukan manusia Melayu moden di Malaysia: suatu analisa. Jurnal Pengajian Melayu 15: 19-51.

Sayyid Qutb. 1982. Fi Zilal al-Quran. Jil. 5 \& 6. Mesir: Dar al-Syuruq

Sohana Abdul Hamid. 2016. Pengaruh Media Massa terhadap Perubahan Sosial Masyarakat. Journal of Sosial Sciences and Humanities (Special Issue). 1(Oktober): 214-226.

Sidang Editor DBP. 1994. Kamus Dewan Bahasa dan Pustaka. $3^{\text {rd }}$ Edition. Kuala Lumpur: Dewan Bahasa danPustaka.

Al-Sha'rān̄̄, Abd. al-Wahhāb bin Aḥmad. 1954. Al-Ṭabaqāt al-Kubrā:al-Mussamat bi Lawāqih al-Anwār fì Ṭabaqāt al 'Akhyār. Vol.2. Mesir: Matba'ah Muștafā al-Bābī al-Halābī.

Al-Sullamī, Abū 'Abd.Raḥmān. 1969. Tabaqāt al-Sufiyyah. Nūr al-Dīn Syaribah Al-Halābī (pnyt.). n. p.: n. p.

Al-Suhrawardī, Syihāb al-Dīn. 1966. 'Awārif al-M'ārif. Lubnan: Dār al-Kitāb al-'Arab̄i.

Al-Syak'ah, Musțafā. 1996. Islām bilā Mazāhib. Kaherah Dārul Masriyyah al-Lubnāniyyah.

Al-Taftāzan̄̄, Abū al-Wafā' al-Ghanīmī. 1976. Madkhal ilā al-Tașawwuf al-Islāmī. Kaherah: Dār al-Ṭawafah.

Al-Tusī, Nașr al-Sarraj.1960. Al-Luma’. Mesir: Dār al-Kutub al-Hadīthah.

Yusoff Mohamad.1989. Bina Insan: Satu analisis kaedah. Kuala Lumpur: Nurin Enterprise

Wan Mohd. Nor Wan Daud. 2001. Pembangunan di Malaysia: kearah suatu kefahaman baru yang lebih sempurna. Kuala Lumpur: ISTAC

Wan Norina W.H., Zaharah H., Ahmad F.,Mohamed Y, Ahmad Ariffin. 2013. Pengaruh Media

Massa Terhadap Penampilan Akhlak Pelajar Islam Politeknik Malaysia. The Online Journal of Islamic Education 1 (1):17-27

Zakaria Stapa. 1999. Akidah dan akhlak dalam kehidupan Muslim. Kuala Lumpur: Utusan Publications \& Distributors Sdn. Bhd.

Zakaria Stapa. 2004. Tasawuf dan Pembangunan Hakiki Ummah. Dalam Wan Suhaimi Wan Abdullah \& Che Zarrina Sa'ari (Ed.). Tasawuf dan Ummah. pp. 55-84. Kuala Lumpur: Jabatan Akidah dan Pemikiran Islam, API, UM.

Zakaria Stapa. 2015. Memasyarakatkan Kefahaman dan Amalan Ilmu Tasawuf di Malaysia Masa kini. Bangi: Fakulti Pengajian Islam, UKM 